\title{
Estimation of size selectivity of fish species caught by different gears in the old Brahmaputra River
}

\author{
I. S. Saberin ${ }^{1}$, M. S. Reza ${ }^{1^{*}}$, N. J. Ayon ${ }^{2}$ and M. Kamal ${ }^{2}$ \\ ${ }^{1}$ Department of Fisheries Technology, Bangladesh Agricultural University, Mymensingh 2202, Bangladesh, and \\ ${ }^{2}$ Department of Pharmaceutical Technology, Faculty of Pharmacy, University of Dhaka, Dhaka-1000 Bangladesh, \\ *E-mail: rezams@gmail.com
}

\begin{abstract}
Over the last couple of decades, the old Brahmaputra River, one of the ancient river systems of Bangladesh, has fallen in verge of biodiversity changes affecting its range of fauna and flora. Study was, therefore, conducted to investigate the selectivity of fish species caught by different fishing gears used in the old Brahmaputra River system over a period of 1 year. $L_{50 \%}$ of different gears was determined mainly for dominant species where 41 fish species were recorded. Highest $\mathrm{L}_{50 \%}$ was recorded in gill net (fash jal) followed by basket trap (vair) whereas lowest value was recorded for seine net. Seine net, cast net, sidi bair and hand line (borshi) were considered non selective gears where fash jal and sidi bair were regarded as gear specific for large fish species and koi jal, ber jal, dharma jal, howra bair and koach were considered specific for small species. Among all the gears, seine net, cast net, koi jal and howra bair were found to be harmful for small species of fishes. Monofilamentous gill net (current jal) although marked as banned gear, was found to be operated in the river and causing considerable damage to the fish stock. Fash jal was considered as harmful gear for catfish as it was found to be used to catch fishes below legal size. It is suggested that fash jal should be restricted for several months, which may allow the newly stock fingerlings to grow to market size.
\end{abstract}

Keywords: Biodiversity, Fish species, Fishing gears, The Old Brahmaputra river

\section{Introduction}

Bangladesh is topographically a deltaic plain criss-crossed by innumerable rivers and rivulets and has a great fisheries potential. Riverine fishing areas comprise nearly one fifth of the entire fishing area of 4.9 million ha of the country (DoF, 2013). Its capture fisheries in the form of common property and open access resources constitute a vital component of the agro-ecosystem of rural Bangladesh. It is also a very important source of household welfare for millions of rural poor, particularly for providing nutrition (specially the much needed protein), income and employment. Thus, the fisheries resources offer excellent opportunities for increased fish production that will effectively combat malnutrition and generate additional employment. Approximately 1.4 million people are directly engaged in fishing, 11 million in part time fishing and another 3 million in aquaculture activities (Hussain, 2010). In addition, it provides opportunities for about $70 \%$ of rural population in subsistence fishing for their own consumption. Quite a significant number of people are engaged in other related activities such as fish fry collection, fish trading, processing, net/trap and boat making, fisheries labor etc.

The old Brahmaputra River was the main flow of the Brahmaputra-Jamuna river system and rich in different fish fauna. The biodiversity of this river system has changed over the last couple of centuries, but still it is regarded as one of the most productive freshwater ecosystem of Bangladesh. The water supply of this river system is has been reported to be greatly affected due to huge withdrawal of water from the upstream parts of the river located in India (Mortuza, 2007).

Different types and form of gears have been operated in the old Brahmaputra River to exploit wild fishes. The intensity of use of any form of gear in a river is dependent on the intensity of target fish population presumed to be available in that river. Some of the gears are selective for a particular species, whereas other account for a number of species caught during operation giving multi-species nature of the fishing. Among them, many of these have been known to catch carp fingerlings before they grow to legal size and many of these responsible for sharp decline in the population of wild species from the river of the country. However, operation of all types of gear cannot be kept suspended to allow the stocked fingerlings and also wild fishes to grow. Only a few studies have been undertaken on the status of resources as well as the causes of declining resources in the old Brahmaputra River. The intensity of fishing gears, mesh sizes and catch per unit effort are good indicators of the status of exploitation level of river. 
Considering the above circumstances, the present study was undertaken on the basis of the following objectives i) to identify the fishing gears operated in the old Brahmaputra River, ii) Size (length) selectivity of the species caught by different fishing gears with the potential to formulate the better management practices to conserve the resources.

\section{Materials and Methods}

\section{Study area}

The study was conducted in the area of Mymensingh sadar upzilla where the river runs from Kagdahor, Kachari, Shomvogonj, Kawatkhali Railway Bridge, BAU campus, Shesmor and Sutiakhali. The investigation have also included the Char-kalibari, the Char-gobaida, and the Char-nilakshia.

\section{Data Collection}

The catch data were collected from fish landing centers, markets and the fishing spot individually for a period starting from April, 2011 to March, 2012. Catch composition of each type of gear was recorded by physical examination of the total catch, most of the time the total catch was purchased from the fishermen on the spot. Then the samples were sorted out species wise and measurement total length of individual fish of each species. For each type of gear, the samples were collected from different spots (each collection is the catches of a fishing unit with a type of gear) to obtain the desired size of sample population (the number of fish those have been measured), i.e., at least 100 fish for a dominant species in a given gear. But less than 100 fish were considered as dominant species due to its less availability.

\section{Data Analysis}

Collected information on species composition in each type of gear was analyzed to determine the species and length selectivity. $L_{50} \%$ value and selection range $\left(L_{25 \%}-L_{75 \%}\right)$ were determined for each dominant species. To estimate size (length) selectivity of the species caught in gear, the $L_{50 \%}$ value and selection range $\left(L_{25 \%}-L_{75 \%}\right)$ were calculated for each dominant species with the help of linear probit regression. The $L_{50 \%}$ is the length at which $50 \%$ of the fish entering the gear are retained and $50 \%$ escape. It is also called "length at first capture". The selection range is the range of the lengths between $L_{25 \%}$ (the length at which $25 \%$ of fish entering the gear are retained) and $L_{75 \%}$ (the length at which $75 \%$ of fish entering the gear are retained). The $50 \%$ retention length and the selection ranges (25\% and $75 \%)$ were evaluated according to Pope et al. (1975).

\section{Results and Discussion}

A total 19 types of fishing gears were found to be used by the fishermen for harvesting fish from old Brahmaputra River during the study period (Table 1). The types of gears used are more or less similar with the finding of BCAS (1991) in Halti beel where the fishermen use approximately 30 different types of fishing gear. From the present study, all these types of gears recorded can be broadly classified into nets, traps and hooks and line. Besides these gears, fishermen were also found to catch fish by dewatering the water body and by hand picking. Katha fisheries were also popular and used extensively during dry season by the fishermen.

A total of 41 species of fishes were recorded in the catches of different gears. Data of the found gears were analyzed and results are described below:

\section{Gill net}

The $L_{50 \%}$ value and selectivity range $\left(L_{25 \%}-L_{75 \%}\right)$ of fash jal and koi jal were calculated for dominant species of fish. The $L_{50 \%}$ value and of selectivity range $\left(L_{25 \%}-L_{75 \%}\right)$ of Anabas testudineus $6.25 \mathrm{~cm}$ and $6.36-7.50 \mathrm{~cm}$ in the $2.45 \mathrm{~cm}$ mesh , $8.40 \mathrm{~cm}$ and 8.45-9.50 cm in $3.16 \mathrm{~cm}$ mesh, $9.24 \mathrm{~cm}$ and 8.50$10.22 \mathrm{~cm}$ in $3.6 \mathrm{~cm}$ mesh in June-July, respectively (Table 2). In koi jal $\mathrm{L}_{50 \%}$ values recorded for Anabas testudineus were higher than the values $(8.82 \mathrm{~cm}$ and $8.08-9.54 \mathrm{~cm}$ in $2.5 \mathrm{~cm}$ mesh) recorded by 
Rahman et al. (1992). These differences might be associated with the difference in the mesh sizes of the net. But in the fash jal the $L_{50 \%}$ value and selective range $\left(\mathrm{L}_{25 \%}-\mathrm{L}_{75 \%}\right)$ of Mystus aor $21.24 \mathrm{~cm}$ and 21.25 $22.56 \mathrm{~cm}$ in $6.2 \mathrm{~cm}$ mesh, $22.56 \mathrm{~cm}$ and $22.15-24.56 \mathrm{~cm}$ in $7.4 \mathrm{~cm}$ mesh, $24.25 \mathrm{~cm}$ and $24.50-28.26 \mathrm{~cm}$ in $9.3 \mathrm{~cm}$ mesh, respectively. The values were recorded for Labeo rohita $22.56 \mathrm{~cm}$ and $22.24-24.25 \mathrm{~cm}$ in $6.2 \mathrm{~cm}$ mesh, $24.56 \mathrm{~cm}$ and $24.25-26.50 \mathrm{~cm}$ in $7.4 \mathrm{~cm}$ in mesh, $27.15 \mathrm{~cm}$ and $27.25-30.25 \mathrm{~cm}$ in $9.3 \mathrm{~cm}$ mesh in June-July, respectively (Table 3 ). The $\mathrm{L}_{50 \%}$ value and selective ranges of fash jal $(9-12 \mathrm{~cm}$, mesh) recorded by Paul et al. (1993) in Halti beel were $24.15 \mathrm{~cm}$ and 22.03-26.27 cm for catla and $23.99 \mathrm{~cm}$ and $21.13-26.86 \mathrm{~cm}$ for common carp, respectively. In the present study, the sizes of the fishes recorded in the catches of the gill net (fash jal) were almost similar to the sizes recorded by Paul et al. (1993) in Halti beel but in Chanda beel the sizes of fish were larger due to the use of comparatively large mesh gill net. Through the sizes of carp and catfishes recorded in the present study were just within the limit of legal size, it is suggested to use relatively large mesh size as a better management strategy.

Table 1. Fishing gears used in the old Brahmaputra River

\begin{tabular}{|c|c|c|}
\hline \multicolumn{3}{|c|}{ Types of gear } \\
\hline \multirow[t]{5}{*}{ Fish net } & Gill net & $\begin{array}{ll}1 . & \text { Koi jal } \\
\text { 2. } & \text { Fash jal } \\
\text { 3. } & \text { Current jal }\end{array}$ \\
\hline & Seine net & 1. Ber jal \\
\hline & Lift net & $\begin{array}{ll}\text { 1. } & \text { Vassal/Khorajal } \\
\text { 2. } & \text { Dharma jal } \\
\end{array}$ \\
\hline & Cast net & 1. Jhaki jal \\
\hline & Dragged net & $\begin{array}{ll}\text { 1. } & \text { Thela jal } \\
\text { 2. } & \text { Moiya jal }\end{array}$ \\
\hline Fish Trap & & $\begin{array}{ll}\text { 1. } & \text { Howrabair } \\
\text { 2. } & \text { Sidibair } \\
\text { 3. } & \text { Dughair } \\
\text { 4. } & \text { Vair } \\
\text { 5. } & \text { Bitte } \\
\end{array}$ \\
\hline Hook and Line & & $\begin{array}{ll}\text { 1. } & \text { Kobaborshi } \\
\text { 2. } & \text { Chip borshi } \\
\text { 3. } & \text { Hand borshi } \\
\text { 4. } & \text { Chasra } \\
\end{array}$ \\
\hline Wounding Gear & & 1. Koach \\
\hline Fish Aggregating Device & & 1. Katha \\
\hline
\end{tabular}

Table 2. The $L_{50 \%}$ values and Selectivity ranges $\left(L_{25 \%}-L_{75 \%}\right)$ of gil net (koi jal) for major dominant species in the old Brahmaputra River

\begin{tabular}{|l|l|c|c|c|c|c|c|}
\hline \multirow{2}{*}{ Species } & \multirow{2}{*}{ Month } & \multicolumn{2}{|c|}{$2.45 \mathrm{~cm}$ mesh } & \multicolumn{3}{|c|}{$3.16 \mathrm{~cm}$ mesh } & \multicolumn{2}{c|}{$3.6 \mathrm{~cm}$ mesh } & $\mathrm{L}_{25 \%-} \mathrm{L}_{75 \%}$ & $\mathrm{~L}_{50 \%}$ & $\mathrm{~L}_{25 \%-} \mathrm{L}_{75 \%}$ \\
\cline { 3 - 8 } & & $\mathrm{L}_{50 \%}$ & $\mathrm{~L}_{25 \%-} \mathrm{L}_{75 \%}$ & $\mathrm{~L}_{50 \%}$ & $8.24-9.50$ & 9.24 & $8.50-10.22$ \\
\hline Anabas testudineus (koi ) & June-July & 6.25 & $6.36-7.50$ & 8.40 & 8.45 & \\
\hline
\end{tabular}

\section{Cast net}

Length selectivity of this gear was calculated for 5 dominant species viz. Puntius sarana, P. ticto, Chanda nama, Mystus tengara and Glossogobius giuris caught by three different mesh size from June to October. The $L_{50 \%}$ value and selective ranges of $P$. sarana were recorded $5.65 \mathrm{~cm}$ and $4.15-7.20 \mathrm{~cm}$ in $1 \mathrm{~cm}$ mesh, $6.58 \mathrm{~cm}$ and $6.84-7.50 \mathrm{~cm}$ in $1.5 \mathrm{~cm}$ mesh, $8.50 \mathrm{~cm}$ and $7.25-10.25 \mathrm{~cm}$ in $2 \mathrm{~cm}$ mesh (Table 4). The values of $10.24 \mathrm{~cm}$ and $9.25-12.24 \mathrm{~cm}$ in $1 \mathrm{~cm}$ mesh, $12.58 \mathrm{~cm}$ and $6.75-18.25 \mathrm{~cm}$ in $2 \mathrm{~cm}$ mesh for Glossogobius giuris. The values of $6.25 \mathrm{~cm}$ and $4.36-6.50 \mathrm{~cm}$ in $1 \mathrm{~cm}$ mesh, $10.26 \mathrm{~cm}$ and $10.25-15.36$ $\mathrm{cm}$ in $2 \mathrm{~cm}$ mesh for $M$. tengara. Also the values of $C$. nama were $3.36 \mathrm{~cm}$ and $3.75-4.50 \mathrm{~cm}, 4.85 \mathrm{~cm}$ and $4.50-5.26 \mathrm{~cm}, 6.24 \mathrm{~cm}$ and $6.15-7.25 \mathrm{~cm}$ in $1 \mathrm{~cm}, 1.5 \mathrm{~cm}$ and $2 \mathrm{~cm}$ mesh size, respectively. The $\mathrm{L}_{50 \%}$ value increased with the increased of mesh size in P. sarana, P. ticto, C. nama, M. tengara in July August. For $M$. tengara value increased to change in mesh in July. But the $L_{50 \%}$ value of $P$. sarana more or less similar in $1 \mathrm{~cm}$ and $1.5 \mathrm{~cm}$ mesh in July. The length selectivity value recorded for $P$. sarana and $M$. tengara in the present study were higher to the values obtained by Rahman et al. (1992). 
Table 3. The $L_{50 \%}$ values and Selectivity ranges $\left(L_{25 \%}-L_{75 \%}\right)$ of gill net (fash jal) for major dominant species in the old Brahmaputra River

\begin{tabular}{|l|l|c|c|c|c|c|c|}
\hline \multirow{2}{*}{ Species } & \multirow{2}{*}{ Month } & \multicolumn{2}{|c|}{$6.2 \mathrm{~cm}$ mesh } & \multicolumn{2}{|c|}{$7.4 \mathrm{~cm}$ mesh } & \multicolumn{2}{c|}{$9.3 \mathrm{~cm}$ mesh } \\
\cline { 3 - 9 } & & $\mathrm{L}_{50 \%}$ & $\mathrm{~L}_{25 \%} \mathrm{~L}_{75}$ & $\mathrm{~L}_{50 \%}$ & $\mathrm{~L}_{25 \%}-\mathrm{L}_{75} \%$ & $\mathrm{~L}_{50 \%}$ & $\mathrm{~L}_{25 \%}-\mathrm{L}_{75 \%}$ \\
\hline Mystus aor (Air) & June-July & 21.24 & $21.25-22.56$ & 22.56 & $22.15-24.56$ & 24.25 & $24.50-28.26$ \\
\hline Labeo rohita (Rui) & June-July & 22.56 & $22.24-24.25$ & 24.56 & $24.25-26.50$ & 27.15 & $27.25-30.25$ \\
\hline
\end{tabular}

Table 4. The $L_{50 \%}$ values and Selectivity ranges $\left(L_{25 \%}-L_{75 \%}\right)$ of cast net for major dominant species in the old Brahmaputra River

\begin{tabular}{|c|c|c|c|c|c|c|c|}
\hline \multirow[t]{2}{*}{ Species } & \multirow[t]{2}{*}{ Month } & \multicolumn{2}{|c|}{$1 \mathrm{~cm}$ mesh } & \multicolumn{2}{|c|}{$1.5 \mathrm{~cm} \mathrm{mesh}$} & \multicolumn{2}{|c|}{$2 \mathrm{~cm}$ mesh } \\
\hline & & $\mathrm{L}_{50 \%}$ & $\mathrm{~L}_{25 \%} \mathrm{~L}_{75 \%}$ & $\mathrm{~L}_{50 \%}$ & $\mathrm{~L}_{25 \%} \mathrm{~L}_{75 \%}$ & $\mathrm{~L}_{50 \%}$ & $\mathrm{~L}_{25 \%} \mathrm{~L}_{75 \%}$ \\
\hline \multirow{5}{*}{ Glossogobius giuris(Baila) } & June & 10.24 & $9.25-12.24$ & & & 12.58 & $6.75-18.25$ \\
\hline & July & & & 11.25 & $11.36-12.50$ & & \\
\hline & August & & & 11.50 & $11.45-13.25$ & & \\
\hline & September & & & & & 13.25 & $12.36-16.50$ \\
\hline & October & & & & & 13.52 & $13.62-18.25$ \\
\hline \multirow{4}{*}{ Puntius sarana (Sharputi) } & July & 5.65 & $4.15-7.20$ & 6.58 & $6.84-7.50$ & 8.50 & $7.25-10.25$ \\
\hline & August & & & 6.84 & $6.92-7.21$ & & \\
\hline & September & & & & & 10.24 & $8.81-11.50$ \\
\hline & October & & & & & 10.32 & $8.75-12.36$ \\
\hline \multirow{3}{*}{ Puntius ticto (Tit puti) } & March & 3.56 & $3.25-4.56$ & 4.25 & $4.15-5.36$ & & \\
\hline & April & & & & & 5.26 & $5.12-6.50$ \\
\hline & October & 2.56 & $2.25-3.85$ & & & & \\
\hline Mystus tengara (Tengra) & July & 6.25 & $4.36-6.50$ & & & 10.36 & $10.25-15.36$ \\
\hline Chanda nama(Chanda) & September & 3.36 & $3.75-4.50$ & 4.85 & $4.50-5.26$ & 6.24 & $6.15-7.25$ \\
\hline
\end{tabular}

\section{Seine net}

The $L_{50 \%}$ value and selectivity range $\left(L_{25 \%}-L_{75 \%}\right)$ were determined for five dominant species of fish viz. baim, baila, sharputi, tengra and chanda. The $L_{50 \%}$ value and selective ranges recorded were $15.42 \mathrm{~cm}$ and $13.65-16.36 \mathrm{~cm}$ for Mastacembelus armatus, $5.50 \mathrm{~cm}$ and $4.36-6.25 \mathrm{~cm}$ for G. giuris, $6.15 \mathrm{~cm}$ and $5.25-7.50 \mathrm{~cm}$ for $P$. sarana, $6.50 \mathrm{~cm}$ and $4.68-7.25 \mathrm{~cm}$ for $M$. tengara, $2.75 \mathrm{~cm}$ and $2.25-3.65 \mathrm{~cm}$ for $C$. nama, respectively (Table 5). Colisa fasciatus caught by seine net have less $L_{50 \%}$ value then push net due to smaller mesh size of seine net. The $L_{50 \%}$ value and selectivity range recorded by Rahman et al. (1993) in Halti beel $3.3 \mathrm{~cm}$ and $2.98-3.62 \mathrm{~cm}$ for $C$. nama and $6.21 \mathrm{~cm}$ and $5.07-7.36 \mathrm{~cm}$ for $M$. tengara. These values almost similar with the values recorded by Rahman et al. (1993) but it was to much higher than the values recorded by Rahman et al. (2009).

\section{Lift net}

The length selectivity values of these gears were determined for 6 dominant species of fishes. The $L_{50 \%}$ value and selective ranges were recorded $18.20 \mathrm{~cm}$ and $16.54-21.25 \mathrm{~cm}$ for Mastacembelus armatus, $5.45 \mathrm{~cm}$ and $4.25-6.30 \mathrm{~cm}$ for Puntius sarana $6.17 \mathrm{~cm}$ and $5.43-6.85 \mathrm{~cm}$ for $M$. tengara, respectively (Table 5). These values were more or less similar to the values of $5.74 \mathrm{~cm}$ and $4.24-7.23 \mathrm{~cm}$ for $P$. sarana recorded by Rahman et al. (2009) in Chanda beel.

\section{Push net}

The $L_{50 \%}$ value and selective range were calculated for 5 dominant species. In Colisa fasciatus the values were $6.25 \mathrm{~cm}$ and $5.58-7.56 \mathrm{~cm}$, in $G$. giuris $6.25 \mathrm{~cm}$ and $4.36-6.85 \mathrm{~cm}$, in $P$. sarana $4.58 \mathrm{~cm}$ and 4.36-6.25 cm, in Mystus tengara $6.78 \mathrm{~cm}$ and 6.85-7.15 cm and $C$. nama the values were $3.56 \mathrm{~cm}$ and $3.25-4.50 \mathrm{~cm}$, respectively. The $L_{50 \%}$ values recorded for $G$. giuris were higher than the values recorded in the seine net due to difference of mesh size. 
Table 5. The $L_{50 \%}$ values and Selectivity ranges $\left(L_{25 \%} L_{75 \%)}\right.$ of seine net, lift net and push net for major dominant species in the old Brahmaputra River

\begin{tabular}{|c|c|c|c|c|c|c|c|}
\hline \multirow[t]{2}{*}{ Species } & \multirow[t]{2}{*}{ Month } & \multicolumn{2}{|c|}{ Seine net $(1 \mathrm{~cm} \mathrm{mesh})$} & \multicolumn{2}{|c|}{ Lift net $(1.2 \mathrm{~cm}$ mesh) } & \multicolumn{2}{|c|}{ Push net(1.5 cm mesh) } \\
\hline & & $\mathrm{L}_{50 \%}$ & $\mathrm{~L}_{25 \%} \mathrm{~L}_{75 \%}$ & $\mathrm{~L}_{50 \%}$ & $\mathrm{~L}_{25 \%} \mathrm{~L}_{75 \%}$ & $\mathrm{~L}_{50 \%}$ & $\mathrm{~L}_{25 \%} \mathrm{~L}_{75 \%}$ \\
\hline \multirow[t]{2}{*}{ Colisa fasciatus (Kholisha) } & June & & & 4.25 & $4.36-5.84$ & 6.25 & $5.58-7.56$ \\
\hline & July & 6.25 & $6.36-8.68$ & & & 7.52 & $7.15-8.65$ \\
\hline \multirow[t]{3}{*}{ Mastacembelus armatus (Baim) } & June & 15.42 & $13.65-16.36$ & 18.20 & $16.54-21.25$ & & \\
\hline & July & & & 18.50 & $16.54-21.36$ & & \\
\hline & August & 14.58 & $14.65-15.23$ & & & & \\
\hline \multirow[t]{4}{*}{ Glossogobius giuris (Baila) } & June & 5.50 & $4.36-6.25$ & & & 6.25 & $4.36-6.85$ \\
\hline & July & & & 5.75 & $5.36-6.54$ & & \\
\hline & August & & & 5.92 & $5.36-6.85$ & & \\
\hline & September & 5.45 & $5.23-5.89$ & & & & \\
\hline \multirow[t]{3}{*}{ Puntius sarana (Sharputi) } & June & 6.15 & $5.25-7.50$ & 5.45 & $4.25-6.30$ & & \\
\hline & July & & & & & 4.58 & $4.36-6.25$ \\
\hline & August & 3.45 & $3.58-5.24$ & & & & \\
\hline \multirow[t]{4}{*}{ Mystus tengara (Tengra) } & June & 6.50 & $4.68-7.25$ & 6.17 & $5.43-6.85$ & & \\
\hline & July & & & & & 6.78 & $6.85-7.15$ \\
\hline & August & 4.36 & $4.12-5.89$ & & & & \\
\hline & September & & & 5.36 & $5.24-6.78$ & & \\
\hline \multirow[t]{2}{*}{ Chanda nama (Chanda) } & June & 2.75 & $2.25-3.65$ & & & 3.56 & $3.25-4.50$ \\
\hline & July & & & 3.89 & $3.56-4.87$ & & \\
\hline
\end{tabular}

\section{Traps}

Most of the traps were recorded more or less selective to few species of fishes. In howra bair length selectivity were determined for $M$. armatus, G. giuris and $M$. tengara. The $L_{50 \%}$ value and selective ranges recorded were $16.50 \mathrm{~cm}$ and $15.00-18.25 \mathrm{~cm}$ for $M$. armatus, $5.65 \mathrm{~cm}$ and $4.23-6.50 \mathrm{~cm}$ for $\mathrm{G}$. giuris, $6.45 \mathrm{~cm}$ and $5.25-7.50 \mathrm{~cm}$ for $M$. tengara, respectively (Table 6).

In sidi bair $L_{50 \%}$ value and selective ranges recorded were $4.75 \mathrm{~cm}$ and $4.25-6.50 \mathrm{~cm}$ for $P$. sarana, 15.50 $\mathrm{cm}$ and $14.25-18.50 \mathrm{~cm}$ for Macrognathus pancalus, $3.68 \mathrm{~cm}$ and $3.25-4.50 \mathrm{~cm}$ for Esomus danricus, respectively (Table 6).

Table 6. The $L_{50 \%}$ values and Selectivity ranges $\left(L_{25 \%}-L_{75 \%}\right)$ of Sidi bair, Howra bair and Vair, for major dominant species in the old Brahmaputra River

\begin{tabular}{|c|c|c|c|c|c|c|c|}
\hline \multirow[t]{3}{*}{ Species } & \multirow[t]{3}{*}{ Month } & \multicolumn{6}{|c|}{ Fishing Trap } \\
\hline & & \multicolumn{2}{|c|}{ Howra bair } & \multicolumn{2}{|c|}{ Sidi bair } & \multicolumn{2}{|c|}{ Vair } \\
\hline & & $\mathrm{L}_{50 \%}$ & $\mathrm{~L}_{25 \%} \mathrm{~L}_{75 \%}$ & $\mathrm{~L}_{50 \%}$ & $\mathrm{~L}_{25 \%} \mathrm{~L}_{75 \%}$ & $\mathrm{~L}_{50 \%}$ & $\mathrm{~L}_{25 \%} \mathrm{~L}_{75 \%}$ \\
\hline \multirow[t]{4}{*}{ Mastacembelus armatus (Baim) } & June & 16.50 & $15-18.25$ & & & 16.75 & $15.25-20.24$ \\
\hline & July & & & 17.25 & $17.12-18.52$ & & \\
\hline & August & & & 18.12 & $18.05-20.25$ & & \\
\hline & September & & & & & 15.36 & $16.25-18.65$ \\
\hline \multirow[t]{4}{*}{ Glossogobius giuris (Baila) } & June & 5.65 & $4.23-6.50$ & & & 5.56 & $5.13-6.54$ \\
\hline & July & & & & & 6.58 & $6.36-7.65$ \\
\hline & August & & & 5.36 & $5.21-6.35$ & 6.85 & $6.35-7.84$ \\
\hline & September & 6.45 & 5.65-7.85 & & & & \\
\hline Lepidocephalus guntea (Gutum) & June-July & & & & & 7.25 & $5.5-8.2$ \\
\hline Puntius sarana (Sharputi) & June-July & & & 4.75 & $4.25-6.50$ & 4.35 & $4.25-6.50$ \\
\hline \multirow[t]{3}{*}{ Mystus tengara (Tengra) } & June & 6.45 & $5.25-7.50$ & & & 6.25 & $4.20-6.75$ \\
\hline & July & & & 5.56 & $5.36-6.54$ & & \\
\hline & August & 7.23 & 7.14-8.84 & & & & \\
\hline \multirow[t]{3}{*}{ Macrognathus pancalus (Guchi baim) } & June & & & 15.50 & $14.25-18.50$ & & \\
\hline & July & & & & & 16.47 & $16.45-18.25$ \\
\hline & August & 15.56 & 15.23-16.54 & & & & \\
\hline Esomus danricus (Darkina) & August & & & 3.68 & $3.25-4.50$ & & \\
\hline
\end{tabular}




\section{Hook and line}

In nol borshi the $\mathrm{L}_{50 \%}$ value and selective ranges recorded were for 2 species Channa punctatus and $C$. striatus. The values recorded were $6.72 \mathrm{~cm}$ and $6.57-8.64 \mathrm{~cm}$ for $C$. punctatus, $17.34 \mathrm{~cm}$ and $15.24-$ $24.25 \mathrm{~cm}$ for $C$. striatus (Table 7). But the values were also determined for $L$. calbasu $16.25 \mathrm{~cm}$ and $16.45-20.25 \mathrm{~cm}$ in koba borshi. The values were also determined $16.45 \mathrm{~cm}$ and $15.65-18.25 \mathrm{~cm}$ for $M$. armatus in chip borshi. Rahman et al. (1999) recorded values and selective range $13.02 \mathrm{~cm}$ and $11.54-$ $14.88 \mathrm{~cm}$ for $C$. punctatus in nol borshi. However, from the above finding these gears may be regarded as more or less selective and non detrimental gears in old Brahmaputra River.

Table 7. The $\mathrm{L}_{50 \%}$ values and Selectivity ranges $\left(\mathrm{L}_{25 \%}-\mathrm{L}_{75 \%}\right)$ of Nol borshi, Koba borshi, Chip borshi for major dominant species in the old Brahmaputra River

\begin{tabular}{|c|c|c|c|c|c|c|}
\hline \multirow{3}{*}{ Species } & \multicolumn{6}{|c|}{ Hook and Line } \\
\hline & \multicolumn{2}{|c|}{ Nol borshi } & \multicolumn{2}{|c|}{ Koba borshi } & \multicolumn{2}{|c|}{ Chip borshi } \\
\hline & $\mathrm{L}_{50 \%}$ & $\mathrm{~L}_{25 \%} \mathrm{~L}_{75 \%}$ & $\mathrm{~L}_{50 \%}$ & $L_{25 \%} L_{75 \%}$ & $L_{50 \%}$ & $\mathrm{~L}_{25 \%} \mathrm{~L}_{75 \%}$ \\
\hline Channa punctatus (Taki) & 6.72 & $6.57-8.64$ & & & & \\
\hline Mastacembelus armatus(Baim) & & & & & 16.45 & $15.65-18.25$ \\
\hline Channa striatus (Shol) & 17.94 & $15.24-24.25$ & & & & \\
\hline Labeo calbasu (Kalibaush) & & & 16.25 & $16.45-20.25$ & & \\
\hline
\end{tabular}

\section{Conclusion}

Study on present status of fishing gears operated in the old Brahmaputra River revealed that some gears were selective while others were not which were used to fish in the river. Fash jal with a mesh size greater than $90 \mathrm{~mm}$ was found to be harmless to stocked carp and cat fish, therefore, nets with mesh size $<90 \mathrm{~mm}$ should be regulated during the period June to October. Use of FADs like katha fishery should be prohibited and various awareness/training programs should be extended toward fishers as a rationale for the restrictions on a particular fishing gear during particular season.

\section{References}

Bangladesh Centre for Advanced Studies (BCAS). 1991. Floodplain Production Monitoring. Initial Study Report. BCAS, Dhakha, Bangladesh. 99 pp.

DoF. 2013. Jatiya Matshya Saptah. Department of Fisheries, Government of the Peoples Republic of Bangladesh.

Hussain. M. G. 2010. Freshwater fishes of Bangladesh: Fisheries, Biodiversity and Habitat.

Paul, S.K., Rahman, Razzaque, A. and Chakraborty, B.. 1993. Gear selectivity of the floodplain. Progress Report (June-September 1993). Fisheries Research Institute, TFP, Santahar, Bogra. p. 1-27.

Pope, J., Margetts, A. and Hamely, J.M. 1975. Manual of methods for fish stock assessment. Part III. Selectivity of fishing gear. FAO Fisheries Tecnical Paper, 41 (Rev.1): 65.

Rahman, S., Chakraborty, B., Razzak, A., Paul, S.K. and Chu-Fa, T.S. 1993. The fishing gear selectivity study. Preliminary Progress Report (May, 1993). Fisheries Research Institute, TFP, Santahar, Bogra. p. 1-27.

Rahman, S., Paul, S.K., Chu-Fa, T.S. 1992. The fishing gear selectivity study. Progress Report. Fisheries Research Institute. Thrid fisheries Project, Santahar, Bogra. P.1-20.

Rahman, S., Mazid, M.A., Kamal, M. and Hossain, M.A.1999. Studies on size selectivity caught in fishing gears BSKB beel, a floodplain in Bangladesh.Bangladesh J. Fish. 22 (2): 9-19.

Rahman, S., Razzaaque, A. and Islam, A.K.M.S. 2009. Study of Fishing Gear Selectivity of Chanda Beel, a Floodplain in Bangladesh. American-Eurasian Journal of Sustainable Agriculture, 3(4): 804-815.

Mortuza M.R., Rashid, U.S., Rajib, M.A. and Rahman, M.M. 2007. Temporal Variation Characteristics of Flow and Water Level in the Old Brahmaputra River. In: Report on Climate Change Project No. BUET 20/11 GPN 12, p. 39. 